INTERNATIONAL JOURNAL OF MULTIDISCIPLINARY RESEARCH AND ANALYSis

ISSN(print): 2643-9840, ISSN(online): 2643-9875

Volume 04 Issue 12 December 2021

DOI: 10.47191/ijmra/v4-i12-32, Impact Factor: 6.072

Page No.- 2002-2012

\title{
Why Science Teachers Can't Teach in Informal Learning Environments?
}

\author{
Hakan TÜRKMEN ${ }^{1}$, Gülçin KAPLAN ${ }^{2}$ \\ ${ }^{1}$ Professor at the Department of Mathematics and Science Education, Faculty of Education, Ege University \& Izmir, Turkey, Orcid \\ ID: http://orcid.org/0000-0003-4572-7062 \\ ${ }^{2}$ Master's Student at the Department of Mathematics and Science Education, Institute of Educational Sciences, Ege University \& \\ İmir, Turkey, Orcid ID: https://orcid.org/0000-0002-9705-2258
}

ABSTRACT: Teaching science in informal learning environments (ILE) are of great importance for the science course. In this learning process, students behave like scientists and develop their high-level thinking skills. To establish a connection between daily life and natural sciences is another way to add ILE into formal education. In the literature, many studies declared a few teachers teach science in ILE. The purpose of this study, to determine the difficulties or problems faced by science teachers in the process of science teaching using ILE and what kind of solutions teachers offer about these problems or difficulties. The research was carried out by using descriptive research. The study group consists of 144 science teachers, selecting by easily accessible sampling method, one of the purposeful sampling methods. Ten open-ended questions were asked to the participants. The content analysis method was used to analyze the data. As a result, teachers had problems/difficulties in managerial-based, student-based, parent-based, ILE-based, school location-based, economy-based, curriculum-based and teacher skill and knowledge-based.

KEYWORDS: informal learning environments, science education, teachers' views

\section{INTRODUCTION}

Science in primary and secondary education constitute an important place for our students to develop their scientific identity and plan their career for the future, but it has been observed that students' interest in science has decreased in recent years (Sasson, 2014; Yıldırım \& Şensoy, 2016). One of the reasons of problem is the lack of informal planning offered other than formal education resources (Gerber et al., 2001; Hannu, 1993; as cited in Bozdoğan \& Yalçın, 2006). Studies on science teaching in ILE are aimed at increasing students' academic success in science (Türkmen et al., 2016; Türkmen et al., 2018), improving selfefficacy beliefs (Gürsoy, 2018), strengthening learning (Ertaş et al., 2011), developing interest in science, acquiring scientific interpretation skills (Lin \& Schunn, 2016), attitude, interest, ability, and acquiring scientific thinking skills (Bonnette et al., 2019; Salmi et al., 2017). That reveals the necessity of teaching science lessons in ILE. As a result, the traditional boundaries and role of science educators are changing. Researchers suggests that teachers should have more interest in the field of informal science education. (Pinthong \& Faikhamta, 2018). In the study of Köseoğlu \& Türkmen (2020), science teachers were asked to integrate ILE into their lessons. They concluded that there are number of teachers who are willing to use ILE but teachers applying these environments in their science lessons are very rare. If the reasons why the low number teachers use ILE are investigated, solutions can be produced by identifying the problems and instructional needs that cause this situation. The aim of the study was to determine the difficulties faced by science teachers in the process of teaching science using ILE and what kind of solutions they offered to these difficulties. For the purpose of the research, answers to the following research questions were sought:

- What are the views of science teachers about the problems/difficulties they encounter when applying ILE in their science lessons?

- What are the suggestions of science teachers to solve the problems/difficulties they encounter when applying ILE in their science lessons? 


\section{Why Science Teachers Can't Teach in Informal Learning Environments?}

\section{METHODOLOGY}

In the research, one of the qualitative research methods, descriptive research, was used. This research approach aims to describe a situation that has existed from the past to the present. This research method presents an action or view as it is (Özdemir \& Doğruöz, 2020).

\section{A. Study Group}

The study group of the research consists of 144 science teachers selected by using the "Easily Accessible Sampling" method which is one of the "Purposeful Sampling" methods. In an easily accessible sample, the researcher chooses a situation that is close to him and easy to access. It is the most commonly used research sampling method (Baltacl, 2018). The demographic information of the study group has given in Table 1 .

Table 1. The demographic information of the study group

\begin{tabular}{|c|c|c|c|c|c|c|c|c|c|c|c|c|c|c|c|}
\hline \multirow[b]{2}{*}{ 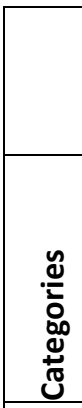 } & \multicolumn{2}{|c|}{ Gender } & \multicolumn{4}{|c|}{ Age } & \multicolumn{4}{|c|}{ Service Years } & \multicolumn{3}{|c|}{ Service Place } & \multicolumn{2}{|c|}{$\begin{array}{l}\text { Getting A } \\
\text { Course } \\
\text { About ISE }\end{array}$} \\
\hline & $\frac{\frac{0}{10}}{\sum \frac{\pi}{2}}$ & 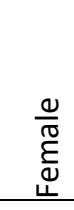 & $\begin{array}{l}\stackrel{P}{+} \\
\stackrel{\sim}{\sim}\end{array}$ & $\begin{array}{l}\text { P } \\
\stackrel{1}{m} \\
m\end{array}$ & $\begin{array}{l}\text { ํ. } \\
\stackrel{-}{+}\end{array}$ & 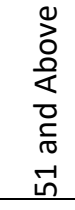 & $\stackrel{\text { L }}{\stackrel{4}{4}}$ & 우 & $\stackrel{\text { 号 }}{\stackrel{-}{-}}$ & $\begin{array}{l}0 \\
0 \\
0 \\
\frac{0}{0} \\
0 \\
0 \\
0 \\
0 \\
0\end{array}$ & 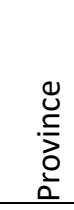 & 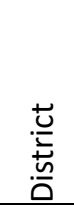 & 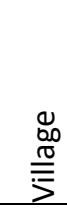 & 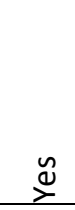 & z \\
\hline f & 55 & 89 & 50 & 60 & 16 & 18 & 41 & 30 & 29 & 44 & 55 & 67 & 26 & 62 & 82 \\
\hline$\%$ & $\begin{array}{l}38, \\
2\end{array}$ & $\begin{array}{l}61, \\
8\end{array}$ & $\begin{array}{l}34, \\
7\end{array}$ & $\begin{array}{l}41, \\
6\end{array}$ & $\begin{array}{l}11, \\
1\end{array}$ & $\begin{array}{l}12, \\
5\end{array}$ & $\begin{array}{l}28, \\
5\end{array}$ & $\begin{array}{l}20 \\
8\end{array}$ & $\begin{array}{l}20, \\
1\end{array}$ & $\begin{array}{l}30, \\
6\end{array}$ & $\begin{array}{l}38, \\
2\end{array}$ & $\begin{array}{l}46, \\
5\end{array}$ & $\begin{array}{l}18, \\
1\end{array}$ & $\begin{array}{l}43, \\
1\end{array}$ & $\begin{array}{l}56, \\
9\end{array}$ \\
\hline
\end{tabular}

*Informal Science Education

\section{B. Data Collection}

A questionnaire consisting of 9 open-ended questions applied to the participants. The data collection tool presented to five expert opinions. In the light of their feedback, the data collection tool was revised and finalized to be applied for the study. In this process, the content validity of the data collection tool was ensured.

\section{Procedure}

The questionnaire, was first published online environment by using the "Google Forms" application. Then, it was delivered to teachers who are teaching science. In order to deliver the data collection tool to science teachers, social media applications and pages/groups in these environments used. To answer the questionnaire takes approximately 10-15 minutes for each participant. When the data of 150 science teachers who answered the questionnaire examined, it was determined that one data was rerecorded three times, four data twice, by the participants due to systemic error. For this reason, 6 data were extracted from the study and 144 data were analyzed.

\section{Data Analysis}

In this study, the data were evaluated by using "Content Analysis Method". To make comment the data were tabulated and calculated frequency distribution (f) and percentage (\%) values. The essential process in content analysis method is to collect similar data within the framework of certain concepts and themes and to organize and interpret these concepts and themes in a way that the reader can understand (Yıldırım \& Şimşek, 2006; as cited in Selçuk \& Palancı, 2014).

\section{FINDINGS}

In this section, the research findings are analyzed for each questions. The first question posed to the participants was "What is the importance of teaching science in ILE for you? Why is that?" Seven teachers' answers were not related to the question but among the rest of them answers, the importance of teaching in ILE was mostly determined by "Hands-on Learning" (28.89\%) and "Effective Teaching / Learning" (25.95\%) (Table-2). 
Why Science Teachers Can't Teach in Informal Learning Environments?

Table 2. Participants' answers regarding the importance of science teaching in ILE

\begin{tabular}{|l|l|l|}
\hline Codes & $\mathbf{f}$ & $\mathbf{\%}$ \\
\hline Hands-on Learning & 57 & 28,89 \\
\hline Effective Teaching / Learning & 55 & 25,95 \\
\hline Associating in Daily Life & 29 & 13,68 \\
\hline Interesting / Fun / Social & 19 & 8,96 \\
\hline Addressing to Sense Organs & 7 & 3,3 \\
\hline Being Different Places/ Experiences & 7 & 3,3 \\
\hline Positive Attitude / Skill Building & 7 & 3,3 \\
\hline Active Learning & 6 & 2,83 \\
\hline Embodying Abstract Concepts & 6 & 2,83 \\
\hline Observing & 5 & 2,36 \\
\hline Achieving to Learning Goals & 4 & 1,89 \\
\hline Motivator & 4 & 1,89 \\
\hline Blocking The Misconceptions & 2 & 0,94 \\
\hline Provides Research and Examination Opportunity. & 2 & 0,94 \\
\hline Supporting Formal Education & 1 & 0,47 \\
\hline Science Literacy & 1 & 0,47 \\
\hline TOTAL & $\mathbf{2 1 2}$ & $\mathbf{1 0 0}$ \\
\hline
\end{tabular}

One example of the answers given by the participants to the first question are as follows:

T19: “... I see informal science teaching very important. Because our students are outside of the monotonous and stereotyped school and classroom environment; I believe that they can learn more permanently in the natural environment ..."

The second question was "Do you encounter "Managerial-Based" difficulties in your process of teaching science in ILE? If so, what are the difficulties? What are your suggestions for solving these difficulties?" In the question, 73 teachers (50.69\%) stated that they encountered difficulties, 64 teachers (44.44\%) stated that they did not, while 7 teachers $(4.86 \%)$ stated answers that were not related to the question. The answers given for encountering difficulties and generating solutions are explained with 11 different codes. The most managerial difficulties were "Legal Permission Procedures" (42.5\%), and the least cited opinions were "Making Extra Assignments" and "Referrals to Out-of-School Hours" (1.25\%) (Table 3).

Table 3. Participants' responses regarding the "Managerial" difficulties

\begin{tabular}{|l|l|l|}
\hline Codes & $\mathbf{f}$ & $\mathbf{\%}$ \\
\hline Permission Procedures & 34 & 42,5 \\
\hline Administration' Failure to Meet the Needs & 15 & 18,75 \\
\hline Administration's/ NED's* not Assuming Responsibility & 8 & 10 \\
\hline "Risky" View (Security Concern) & 6 & 7,5 \\
\hline Considering Activities as Unnecessary/Time Loss & 6 & 7,5 \\
\hline Too Much Bureaucracy & 3 & 3,75 \\
\hline Conditions of Regulations & 3 & 3,75 \\
\hline Exam-Oriented Instruction Expectation & 3 & 3,75 \\
\hline Making Extra Assignments & 1 & 1,25 \\
\hline Referrals to Out-of-School Hours & 1 & 1,25 \\
\hline TOTAL & $\mathbf{8 0}$ & $\mathbf{1 0 0}$ \\
\hline
\end{tabular}

*National Education Directorate

The most opinion of the participants towards a solution is "Communication and/or Cooperation" (27.27\%), while the least mentioned solutions are "Changing the Exam System" and "High population in class" (4.54\%) (Table 4). 
Why Science Teachers Can't Teach in Informal Learning Environments?

Table 4. Participants' answers on the solutions of "Managerial" difficulties

\begin{tabular}{|l|l|l|}
\hline Codes & f & $\%$ \\
\hline Communication and /or Cooperation & 6 & 27,27 \\
\hline Inclusion of Teaching Activities in ILE to Curriculum & 4 & 18,18 \\
\hline $\begin{array}{l}\text { Administration/Ministry of Education Should Take Responsibility / } \\
\text { Be Supportive }\end{array}$ & 4 & 18,18 \\
\hline Permission Procedures Should Be Reduced / Expedited & 3 & 13,63 \\
\hline Bureaucracy Should Be Reduced & 3 & 13,63 \\
\hline Exam System Should Be Changed & 1 & 4,54 \\
\hline High population in class & 1 & 4,54 \\
\hline TOTAL & $\mathbf{2 2}$ & $\mathbf{1 0 0}$ \\
\hline
\end{tabular}

One example of the answers given by the participants to the second question are as follows:

T39: “... I have been asked to get a signed permit from my parents. It was said that we need permission from the district national education. Of course, all this takes 1 week. This process should only be rapid with the approval of the school administration..."

When we ask to the study group "Do you encounter "Student-Based" difficulties in your process of teaching science in ILE? If so, what are the difficulties? What are your suggestions to solve these difficulties?" as the third question. Sixty-one teachers (42.36\%) encountered difficulties and 62 teachers (43.06\%) did not, while 21 teachers' (14.58\%) answers were not related to the question. The most encountered difficulties in the analysis of the difficulties explained by the participants were "Absenteeism/Low Participation" (38.98\%) and the least expressed difficulties were "Mark-Focused Students" and “Communication Problems Between Students" (1.69\%) (Table-5).

Table 5. Participants' responses regarding the "Student-Based" difficulties they encountered

\begin{tabular}{|l|l|l|}
\hline Codes & $\mathbf{f}$ & $\mathbf{\%}$ \\
\hline Absenteeism/ Low Participation & 23 & 38,98 \\
\hline Discipline Problems & 11 & 18,64 \\
\hline Readiness/ Understanding/ Achievement Levels Differences & 4 & 6,78 \\
\hline Adaptation/ Focusing Problems & 4 & 6,78 \\
\hline Lack of Motivation & 3 & 5,08 \\
\hline Do Not Taking Lessons Seriously/ Not Caring & 3 & 5,08 \\
\hline The Difference of Interest Levels About The Lesson & 3 & 5,08 \\
\hline Health Problems & 2 & 3,39 \\
\hline Worker-Child Students & 2 & 3,39 \\
\hline Psychological Problems & 2 & 3,39 \\
\hline Mark-Focused Students & 1 & 1,69 \\
\hline Communication Problems Between Students & 1 & 1,69 \\
\hline TOTAL & $\mathbf{5 9}$ & $\mathbf{1 0 0}$ \\
\hline
\end{tabular}

While the most solutions of student-based difficulties were "Cooperation with Parents, Teachers, Administration and School Guidance Service" (28.57\%) and the least solutions of that difficulties were "Establishing a Science Club", "Informing About the Trip Plan", "Planning Extra Activities After the Trip" and “Increasing Disciplinary Control" (2.38\%) (Table-6).

Table 6. Participants' answers on the solutions of "Student-Based" difficulties

\begin{tabular}{|l|l|l|}
\hline Codes & f & $\%$ \\
\hline $\begin{array}{l}\text { Cooperation with Teachers, Parents, School Guidance Service and } \\
\text { Administration }\end{array}$ & 12 & 28,57 \\
\hline Teaching in ILE Should Be Added to the Curriculum & 5 & 11,9 \\
\hline Short Term Focus Change / Place Organization & 4 & 9,52 \\
\hline Interview & 3 & 7,14 \\
\hline
\end{tabular}


Why Science Teachers Can't Teach in Informal Learning Environments?

\begin{tabular}{|l|l|l|}
\hline Codes & f & $\%$ \\
\hline Encouraging ILE / Explaining Its Importance & 3 & 7,14 \\
\hline Seminars / Courses Should Be Organized & 3 & 7,14 \\
\hline Must be The Repeated Classes Exist & 2 & 4,76 \\
\hline Volunteering is Essential, Do Not Coercion & 2 & 4,76 \\
\hline Trip Repetition Should Be Made For Students Who Couldn't Join & 2 & 4,76 \\
\hline Activities That Increase A Sense of Responsibility & 2 & 4,76 \\
\hline Establishing a Science Club & 1 & 2,38 \\
\hline Informing About The Trip Plan & 1 & 2,38 \\
\hline Planning Extra Activities After the Trip (Ex.: Mall Trip) & 1 & 2,38 \\
\hline Increasing Disciplinary Control & 1 & 2,38 \\
\hline TOTAL & $\mathbf{4 2}$ & $\mathbf{1 0 0}$ \\
\hline
\end{tabular}

One example of the answers given by the participants to the third question are as follows:

T13: "... Absenteeism, invalidity of grading and evaluation (as if the students gained the idea of "somehow I won't repeat this grade") ..."

The next question was, "Do you encounter "Economical-Based" difficulties in your process of teaching science in ILE? If so, what are the difficulties? What are your suggestions for solving these difficulties?" Sixty-one teachers (42.36\%) had difficulties and 62 teachers $(43.06 \%)$ did not, while 21 teachers' $(14.58 \%)$ answers were not related to the question. Among the mentioned difficulties, the high ratio difficulties were "Low-Income Families" (35.44\%) and low ratio difficulties was "Nobody Helps to The Low-Income Families" (1.27\%) (Table-7).

Table 7. Participants' responses regarding the "Economical-Based" difficulties

\begin{tabular}{|l|l|l|}
\hline Codes & $\mathbf{f}$ & $\mathbf{\%}$ \\
\hline Low-Income Families & 28 & 35,44 \\
\hline High Cost Trip From All Directions & 15 & 18,99 \\
\hline Transportation Highly Expensive & 12 & 15,19 \\
\hline School Budget Limited / Insufficient & 6 & 7,59 \\
\hline Village Schools Have Limited Financial Opportunities & 4 & 5,06 \\
\hline Participation Decreases As Costs Increase & 4 & 5,06 \\
\hline High Entrance Fee to ILE. & 4 & 5,06 \\
\hline The Need for Food-Beverage During the Trip & 3 & 3,8 \\
\hline NED Does Not Provide Financial Support & 2 & 2,53 \\
\hline Nobody Helps to The Low-Income Families & 1 & 1,27 \\
\hline TOTAL & $\mathbf{7 9}$ & $\mathbf{1 0 0}$ \\
\hline
\end{tabular}

When the solution about the difficulties were examined, 9 different codes were made. Among the solutions given by 88 teachers, the most were "Administration, Parent-Teacher Association, Teacher and Parent Cooperation" (28.41\%) and "Budget Support" (27.27\%), while the least solutions were "Food-Beverages Should Be Brought from Home", "Schools Should Have Their Own Transportation Vehicles" and "Special Discounts for Students" (1.14\%) (Table-8).

Table 8. Participants' answers on the solutions of "Economical-Based" difficulties

\begin{tabular}{|l|l|l|}
\hline Codes & $\mathbf{f}$ & $\mathbf{\%}$ \\
\hline $\begin{array}{l}\text { Administration, Parent-Teacher Association, Teacher and Parent } \\
\text { Cooperation }\end{array}$ & 25 & 28,41 \\
\hline Budget Support (Municipalities, Ministries, Institutions, Benefactors etc.) & 24 & 27,27 \\
\hline Budget Should Be Allocated (MNE* , School Administrates) & 16 & 18,18 \\
\hline Costless/ Low Cost Lesson Planning Should be Done & 12 & 13,63 \\
\hline Government Should Make Free of Charge to ILE Activities & 6 & 6,82 \\
\hline
\end{tabular}


Why Science Teachers Can't Teach in Informal Learning Environments?

\begin{tabular}{|l|l|l|}
\hline Codes & $\mathbf{f}$ & $\mathbf{\%}$ \\
\hline Teaching in ILE Should Be Disseminated & 2 & 2,27 \\
\hline Schools Should Have Their Own Transportation Vehicles & 1 & 1,14 \\
\hline Special Discounts for Students & 1 & 1,14 \\
\hline Food-Beverages Should Be Brought from Home & 1 & 1,14 \\
\hline TOTAL & $\mathbf{8 8}$ & $\mathbf{1 0 0}$ \\
\hline
\end{tabular}

* Ministry of National Education

One example of the answers given by the participants to the fourth question are as follows:

T18: “... Not every student's family can afford to pay this money. Generally, if the money is involved, the plans are cancelled. Nevertheless, as a solution, Ministry of Education may allocate a budget for such training."

Fifth question was "Do you encounter Parent-Based difficulties in your process of teaching science in ILE? If so, what are the difficulties? What are your suggestions for solving these difficulties?" While the number of participants who encountered difficulties was 83 (57.64\%), 59 participants did not encounter difficulties. Unfortunately, 68 responses came from 83 teachers faced parent-based difficulties, which showed us that some teachers had difficulties but did not need to explain this. The expressions related to the described difficulty are collected under 10 different codes. While the codes with the highest frequency is "Unknowledgeable Parents" (23.53\%), and the lowest frequency is "Students Living in Dormitories" (1.47\%)" (Table 9).

Table 9. Participants' responses regarding the "Parent-Based" difficulties

\begin{tabular}{|l|l|l|}
\hline Codes & $\mathbf{f}$ & $\mathbf{\%}$ \\
\hline Unknowledgeable Parents & 16 & 23,53 \\
\hline Anxiety of Safety & 14 & 20,59 \\
\hline Unwilling Parents & 13 & 19,12 \\
\hline Low-Income Families & 12 & 17,65 \\
\hline Misinforming Students & 8 & 11,76 \\
\hline Sending Or Not Signing a Travel Permit Form Late & 4 & 5,88 \\
\hline Test-Oriented Teaching Expectation for LGS & 3 & 4,41 \\
\hline Parents Who Don't Want to Send Their Girls & 2 & 2,94 \\
\hline Parents with Low Education Level & 2 & 2,94 \\
\hline Students Living in Dormitories & 1 & 1,47 \\
\hline TOTAL & $\mathbf{6 8}$ & $\mathbf{1 0 0}$ \\
\hline
\end{tabular}

*LGS: Exam of Transition to High School

The science teachers who made suggestions for the difficulties encountered were mostly "Incentive to Support Teaching in ILE (Awareness)" (26.42\%) and the lowest solutions frequency was "Experienced Teachers Should Organize a Trip" and "Needs Based Lesson Planning" solutions are at least specified (1.89\%) (Table-10).

Table 10. Participants' answers on the solutions of "Economical-Based" difficulties

\begin{tabular}{|l|l|l|}
\hline Codes & $\mathbf{f}$ & $\mathbf{\%}$ \\
\hline Encouragement to Support Teaching in ILE (Raising Awareness) & 14 & $\mathbf{2 6 , 4 2}$ \\
\hline School Guidance Service (Teacher-Parents Interviews) & 12 & 22,64 \\
\hline The Benefits of ILE Should Be Promoted (Ex: Public Service Ad) & 6 & 11,32 \\
\hline Including Parents in the Travel Process & 5 & 9,43 \\
\hline Reservations Should Be Minimized & 4 & 7,55 \\
\hline Parent Education (Seminars) & 4 & 7,55 \\
\hline Parent Meeting Before the Trip (Information about the Process) & 3 & 5,66 \\
\hline Correct and Effective Communication & 3 & 5,66 \\
\hline Experienced Teachers Should Organize The Trips & 1 & 1,89 \\
\hline A Lesson Based on Needs Should Be Planned & 1 & 1,89 \\
\hline TOTAL & $\mathbf{5 3}$ & $\mathbf{1 0 0}$ \\
\hline
\end{tabular}




\section{Why Science Teachers Can't Teach in Informal Learning Environments?}

One example of the answers given by the participants to the fifth question are as follows:

T30: "... They didn't want to send their girls to a different environment in the east ..."

As the sixth question, "Do you encounter Curriculum-Based difficulties in your process of teaching science in ILE? If so, what are the difficulties? What are your suggestions for solving these difficulties? was directed to the study group. The 59 participants answered "Yes, I encounter difficulties" (40.97\%), 62 answered "No, I do not encounter difficulties" (43.06\%) and 23 answered unrelated to the question (15.97\%). Each teacher who stated that they encountered difficulties made an additional explanation and collected 59 statements in total under 5 code titles. The highest frequency of difficulties was the "Insufficient Class Time" $(83.05 \%)$ and the lowest frequency of difficulties was “People Don't Give Importance to Science" (1,69\%) (Table 11).

Table 11. Participants' responses regarding the "Curriculum-Based" difficulties

\begin{tabular}{|l|l|l|}
\hline Codes & $\mathbf{f}$ & $\mathbf{\%}$ \\
\hline Insufficient Class Time & 49 & 83,05 \\
\hline The Content of the Curriculum is Very Intensive & 5 & 8,47 \\
\hline Students' / Teachers' Concern about Raising Topics & 2 & 3,39 \\
\hline Due to LGS, We Can't Organize Activities & 2 & 3,69 \\
\hline People Don't Give Importance to Science & 1 & 1,69 \\
\hline TOTAL & $\mathbf{5 9}$ & $\mathbf{1 0 0}$ \\
\hline
\end{tabular}

Sixty-two responses given as a solution to curriculum-based difficulties were gathered under 11 codes. The "Cooperation Between Teachers" (24.19\%) was the highest frequency ratio, but "Support and Training Courses Should Be Opened for Lesson Planning in ILE", "Students' Should Be Separated as Numeric or Verbally" and interestingly "The Frequency of Teaching in ILE Should Be Reduced" (1.61\%) were the lowest frequency ratio (Table-12).

Table 12. Participants' responses regarding the "Curriculum-Based" difficulties

\begin{tabular}{|l|l|l|}
\hline Codes & $\mathbf{f}$ & $\mathbf{\%}$ \\
\hline Cooperation Between Teachers & 15 & 24,19 \\
\hline Increasing The Class Time & 12 & 19,35 \\
\hline A Lesson Based on Needs Should Be Planned & 7 & 11,29 \\
\hline Make-up Classes & 7 & 11,29 \\
\hline Teaching in ILE Should Be Added to the Curriculum & 6 & 9,68 \\
\hline Organizing Trips Out of Class Times & 6 & 9,68 \\
\hline Curriculum Should be Revised & 4 & 6,45 \\
\hline Doing Group Works & 2 & 3,23 \\
\hline Students' Should be Separated as Numeric or Verbally & 1 & 1,61 \\
\hline The Frequency of Teaching in ILE Should be Reduced & 1 & 1,61 \\
\hline $\begin{array}{l}\text { Support and Training Courses Related to Lesson Planning in ILE Should } \\
\text { Be Opened }\end{array}$ & 1 & 1,61 \\
\hline TOTAL & $\mathbf{6 2}$ & $\mathbf{1 0 0}$ \\
\hline
\end{tabular}

One example of the answers given by the participants to the sixth question are as follows:

T67: “...The fundamental problem is; students and teachers may be worried about not being able to catch up with other classes..."

"Do you encounter difficulties in your process of teaching science in ILE due to "The Field of School/Physical Environment? If so, what are the difficulties? What are your suggestions for solving these difficulties?" was the seventh question. There were 45 teachers (31.25\%) who answered "Yes, I have difficulties", 88 teachers (61.11\%) who answered "No, I do not encounter" and 11 teachers' (7.64\%) answer were not related to the question. In the seventh question, 40 explanations from 45 teachers were gathered under 2 themes and 7 codes. In the first theme, "ILE \& School-related Issues", the highest difficulty was "Number of ILE Around School is Low / No" (40\%) and the lowest difficulty was "School's Environment Is Not Safe" (2.5\%). In the other theme, "School-related Issues", the highest difficulty was "The Lack of Afforestation at The School" (12.5\%), the lowest difficulty was "Crowded Population in Classes" and "The Presence of Bussed Students" (5\%) (Table-13). 
Why Science Teachers Can't Teach in Informal Learning Environments?

Table 13. Participants' responses regarding the "The Field of School / Physical Environment" difficulties

\begin{tabular}{|l|l|l|l|}
\hline Themes & Codes & $\mathbf{f}$ & $\mathbf{\%}$ \\
\hline \multirow{4}{*}{ ILE \& School-related Issues } & Number of ILE Around School is Low / No & 16 & 40 \\
\cline { 2 - 4 } & There is No ILE Other Than Nature / Far in Village & 10 & 25 \\
\cline { 2 - 4 } & School's Environment Is Not Safe & 1 & 2,5 \\
\hline \multirow{4}{*}{ School-related Issues } & The Lack of Afforestation & 5 & 12,5 \\
\cline { 2 - 4 } & The Absence of Laboratories & 4 & 10 \\
\cline { 2 - 4 } & Crowded Population in Classes & 2 & 5 \\
\cline { 2 - 4 } & Bussed Students & 2 & 5 \\
\hline TOTAL & & $\mathbf{4 0}$ & $\mathbf{1 0 0}$ \\
\hline
\end{tabular}

While not all of the teachers who had difficulties were able to offer solutions, only 9 solutions were recorded as data. The highest frequency of solutions was "Government Should Reserve Budget/Provide Resources" (24\%) and the lowest frequency of solutions was "Lesson Plans Prepared for Needs" (8\%) (Table-14).

Table 14. Participants' answers on the solutions of "The Field of School / Physical Environment " difficulties

\begin{tabular}{|l|l|l|}
\hline Codes & $\mathbf{f}$ & $\mathbf{\%}$ \\
\hline Government Should Reserve Budget / Provide Resources & 6 & 24 \\
\hline ILE Should Be Reachable (Transport Museums etc.) & 4 & 16 \\
\hline Teachers/ Administration Should Make Effort & 4 & 16 \\
\hline Cooperation (School, Parent-Teacher Association etc.) & 3 & 12 \\
\hline Excursions Outside the Province / District Should Be Organized & 3 & 12 \\
\hline Virtual Environments / Technology Can Be Used (Ex: Virtual Aquarium) & 3 & 12 \\
\hline Lesson Plans Prepared for Needs & 2 & 8 \\
\hline TOTAL & $\mathbf{2 5}$ & $\begin{array}{l}\mathbf{1 0} \\
\mathbf{0}\end{array}$ \\
\hline
\end{tabular}

One example of the answers given by the participants to the seventh question are as follows:

T18: "... There are no such opportunities in the villages and it is very far away, so school trips will only happen if someone arranges a service..."

The eight question was "Do you encounter ILE-Based difficulties in the ILE in which you plan to apply your science teaching process? If so, what are the difficulties? What are your suggestions for solving these difficulties?" While Fifty-one teachers (35.42\%) who answered "Yes, I encounter difficulties", 77 teachers (53.47\%) who answered "No, I don't encounter" and 16 teachers' answers were not related to the question (11.11\%). It was seen that among the 51 science teachers' answers, the most common problem was "Far Away" (54.55\%). "Not Safe", "Not Suitable for Weather Conditions" (3.03\%) was the least experienced difficulties (Table-15). These expressions showed that ILE are only institutions, such as museums, zoo and botanical gardens, aquariums, etc., but nature, non-governmental organizations, industrial factories, etc. were out of their minds.

Table 15. Participants' responses regarding the "ILE-Based" difficulties

\begin{tabular}{|l|l|l|}
\hline Codes & $\mathbf{f}$ & $\mathbf{\%}$ \\
\hline Far away & 18 & 54,55 \\
\hline COVID-19 Pandemic & 8 & 24,24 \\
\hline Entrance Fee Is Expensive & 2 & 6,06 \\
\hline Difficult to Get an Appointment & 2 & 6,06 \\
\hline Not Safe & $\mathbf{2}$ & 6,06 \\
\hline Not Suitable for Weather Conditions & 1 & 3,03 \\
\hline TOTAL & $\mathbf{3 3}$ & $\mathbf{1 0 0}$ \\
\hline
\end{tabular}

Among the 32 solutions stated by the participants regarding the ILE-based problems, there are only 3 suggestions related to the question, while the other suggestions are administrative, economic and teacher-based solutions. Suggestions for solving 


\section{Why Science Teachers Can't Teach in Informal Learning Environments?}

difficulties based on ILE were "The Number of ILE Should Be Increased/Improved" (9.38\%) and "Natural Environments Can Be Chosen" (3.13\%) (Table-16).

Table 16. Participants' answers on the solutions of "ILE-Based" difficulties

\begin{tabular}{|l|l|l|l|}
\hline \multirow{4}{*}{ Related } & Codes & $\mathbf{f}$ & $\mathbf{\%}$ \\
\hline & The Number of ILE Should Be Increased/ Improved & 3 & 9,38 \\
\cline { 2 - 4 } & Should be Visited Before Lesson Planning & 2 & 6,25 \\
\cline { 2 - 4 } & Natural Environments Can Be Chosen & 1 & 3,13 \\
\hline \multirow{5}{*}{ Not Related } & A Lesson Based on Needs Should Be Planned & 13 & 40,63 \\
\cline { 2 - 4 } & Transport Must Be Replicated/Public Transport Can Be Used & 5 & 15,63 \\
\cline { 2 - 4 } & Government Should Reserve Budget & 3 & 9,38 \\
\cline { 2 - 4 } & Effective Communication & 2 & 6,25 \\
\cline { 2 - 4 } & Annual Planning Should Be Made & $\mathbf{2}$ & 6,25 \\
\cline { 2 - 4 } & Cancelling The Trip & 1 & 3,13 \\
\hline TOTAL & & $\mathbf{3 2}$ & $\mathbf{1 0 0}$ \\
\hline
\end{tabular}

One example of the answers given by the participants to the eighth question are as follows:

T101: "...Being far away, financial and moral difficulties. Weather conditions are not very suitable for these regions..."

The final question was "Do you encounter any instructional/pedagogical based difficulties in your planning/ implementation/ evaluation process of science teaching activities in ILE? If so, what are the difficulties? What are your suggestions for solving these difficulties?" While $58.33 \%$ of the teachers had instructional / pedagogical based difficulties, $37.5 \%$ did not have experience and $4.17 \%$ did not answered. Sixty answers from teachers who had instructional / pedagogical based difficulties were categorized in 8 codes. The highest frequency of difficulties was "Managing / Planning the Teaching Process in ILE" (33.33\%) and the lowest frequency of difficulties were "Disagreements with the School Administration" and "Motivating Students" (2.38\%) (Table-17). This data showed that our teachers have deficiencies in lesson planning in ILE because of their lack of knowledge and experience.

Table 17. Participants' responses regarding the "Instructional / Pedagogical-Based" difficulties

\begin{tabular}{|l|l|l|}
\hline Codes & $\mathbf{f}$ & $\mathbf{\%}$ \\
\hline Managing / Planning the Teaching Process in ILE & 20 & 33,33 \\
\hline Student-Based Problem Solving Skill & 15 & 25 \\
\hline Teachers' Negative Prejudices in Teaching ILE & 10 & 16,67 \\
\hline Inadequate Material and Educational Technology & 5 & 8,33 \\
\hline Classroom Management & 5 & 8,33 \\
\hline Student Safety & 3 & 5 \\
\hline Disagreements with the School Administration & 1 & 1,67 \\
\hline Student Motivation & 1 & 1,67 \\
\hline TOTAL & $\mathbf{6 0}$ & $\mathbf{1 0 0}$ \\
\hline
\end{tabular}

Among the 39 solutions made by the teachers regarding the difficulties experienced, the most solutions were "In-Service Trainings / Seminars for Teaching in ILE" (38.46\%) and "the least solutions were "Planning with Students" (2.56 \%) (Table-18).

Table 18. Participants' answers on the solutions of "Instructional / Pedagogical-Based" difficulties

\begin{tabular}{|l|l|l|}
\hline Codes & $\mathbf{f}$ & $\mathbf{\%}$ \\
\hline In-Service Seminars for Teaching in ILE & 15 & 38,46 \\
\hline School Guidance Service / Colleague / Parent & 9 & 23,08 \\
\hline Planning Should be Made by Visiting The ILE Before The Trip & 2 & 5,13 \\
\hline Expert Assistance & 2 & 5,13 \\
\hline Preparing ILE Activities for Students & 2 & 5,13 \\
\hline Follow-up of Books / Projects Subject to ILE & 2 & 5,13 \\
\hline
\end{tabular}


Why Science Teachers Can't Teach in Informal Learning Environments?

\begin{tabular}{|l|l|l|}
\hline Codes & f & \% \\
\hline Student Population Should Be Reduced & 2 & 5,13 \\
\hline Raising Awareness of Students & 2 & 5,13 \\
\hline Planning with Students & 1 & 2,56 \\
\hline Teacher's Personal Professional Development Effort & 1 & 2,56 \\
\hline TOTAL & $\mathbf{3 9}$ & $\mathbf{1 0 0}$ \\
\hline
\end{tabular}

One example of the answers given by the participants to the ninth question are as follows:

T100: "...Students may have incomplete learning or lack of motivation and motivation in the application part..."

\section{CONCLUSION AND DISCUSSION}

In the light of the findings, science teachers were not enough aware of the importance of science teaching in ILE, but science teachers having experience teaching science in ILE faced many difficulties and they could suggest some solutions about these difficulties. Considering these difficulties, it is very obvious to say that some science teachers not having experience in science teaching in ILE thought it is unnecessary to teach science in ILE. This result is very similar to study of Bostan and friends (2017). Clearly, they do not know how to make proper science lesson plan and how to solve student-based problems the lesson in ILE, because of their lack experience and knowledge level. In addition, teachers complain about the administrative permission for teaching science in ILE because school administration are not very helpful in this process. The permission procedures are very tiring, intense and long process. This is also parallel result with many studies, such as Ekinci et al. (2020), Köseoğlu \& Türkmen (2020) studies. Another big complain stated by science teachers is that students were absent science lessons in ILE for various reasons. That is impossible to make up the lesson they missed so this problem causes to decrease the students' academic achievements. Moreover, the difficulties of disciplining students and classroom management in science lessons in ILE are obvious. The solution of such difficulties depends on the cooperation of the parent, teacher, school guidance service and school administration. Teachers also highlight the economic problems that are difficult for such organizations to take place with low budget of school and low socio-economic level of families. If we add transportation problems, uneducated and unwillingness of the families, and also security problems, it puts our enthusiastic teachers into difficulties. Teachers think that if the government increase the state contribution and we can find various sponsors, the economic problems could be solved. The distance between ILE and the location of the school is another reason why teachers cannot use ILE. Because teachers perceive only institutions such as museums, zoos and botanical gardens etc. as ILE, these type of ILE are not enough around to schools. At this point, the biggest expectation was to increase "School Administration Budget". A few participants pointed out to "Virtual Environments" as ILE. This result could be accepted as a sign that the technology will solve some of the difficulties. Our teachers, who have experienced a competitive education process in our country, encounter problems of implementation ILE into their science curriculum. Because, they feel obliged to do test-oriented studies due to anxiety of finishing the science subjects until the end of the semester and the LGS (Exam of Transition to High School) that senior students must take. Thus, they have got prejudges to implement ILE into their science curriculum. However, some science teachers handle this problem via to take day-off permission from the school administration or to switch their lessons with other teachers.

As a result, although teachers' lack of knowledge and experience, economic problems, administrative problems, insufficient school programs, uneducated and unwilling families, even teachers' prejudice, time problem and being in the pandemic process are some obstacles to integrate ILE to science lessons. These obstacles negatively affect the motivation of most teachers. On the other hand, there is always hope, a few teachers declared that "I know, there are some problems but these problems do not affect my motivation negatively, on the contrary, it makes me spend more effort because it is worth everything for students".

\section{REFERENCES}

1) Baltacı A. (2018). A conceptual review of sampling methods and sample size problems in qualitative research. Journal of Bitlis Eren University, 7(1), 231-274.

2) Bostan, Sarıoğlan A., \& Küçüközer, H. (2017). Investigation of preservice Science teacher' opinions regarded to outdoor school learning environments. Journal of Research in Informal Environments, 2(1), 1-15.

3) Bonnette, R.N., Crowly, K. \& Shunn, C.D. (2019). Falling in love and staying in love with science: ongoing informal science experiences support fascination for all children. International Journal of Science Education. 41(12), 1626-1643. https://doi.org/10.1080/09500693.2019.1623431 


\section{Why Science Teachers Can't Teach in Informal Learning Environments?}

4) Bozdoğan, A.E. \& Yalçın, N. (2006). The effects of science centers on the change of "science interest" levels of primary education students and on their academic success: energy park, Ege Journal of Education, 2(7), 95-114.

5) Ekinci, S., Oktay, Ö., \& Şen, A. İ. (2020). A mobile planetarium activity: investigation of middle school teachers' views. Gazi University Journal of Gazi Educational Faculty, 40(3), 827-852.

6) Ertaş, H., Şen, A. İ., \& Parmaksızoğlu, A. (2011). The effects of out-of school scientific activities on 9th grade students' relating the unit of energy to daily life. Electronic Journal of Science and Mathematics Education, 5(2), 178-198. https://doi.org/10.17522/nefefmed.3929

7) Gürsoy, G. (2018). Outdoor learning environments in science education. Journal of Turkish Studies, 13(11), 623-649. https://doi.org/10.7827/turkishstudies.13225

8) Köseoğlu, P. \& Türkmen, H. (2020). Perspectives of science teacher about science teaching in informal setting. Journal of Research in Informal Environments, 5(1), 44-58.

9) Lin, P.Y. \& Shunn, C.D. (2016). The dimensions and impact of informal science learning experiences on middle scholars' attitudes and abilities in science. International Journal of Science Education. http://dx.doi.org/10.1080/09500693.2016.1251631

10) Özdemir, M. \& Doğruöz, E. (2020). Scientific Research Patterns. Cemaloğlu, N. , Scientific Research Techniques and Ethics, (p.65-102). Pegem Academy.

11) Pinthong, T., \& Faikhamta, C. (2018). Research trends and issues in informal science education. AIP Conference Proceedings, 1923(January), 030039. https://doi.org/10.1063/1.5019530

12) Salmi, H., Thuneberg, H., \& Vainikainen, M. P. (2017). Making the invisible observable by augmented reality in informal science education context. International Journal of Science Education, Part B: Communication and Public Engagement, 7(3), 253-268. https://doi.org/10.1080/21548455.2016.1254358

13) Selçuk, Z. \& Palancı, M. (2014). Trends of researches published in education and science journal: content analysis. Education and Science Journal, 173(39), 430-453.

14) Türkmen, H., Doğru, Ö., \& Şükran, Ö., (2018). Teaching science in informal learning environments: secondary school students views about the excursion in sasalı nature wildlife park. Turan-Sam International Scientific Peer-Reviewed Seasonal Journal, 10(40), 641-650.

15) Türkmen, H., Topkaç, D. D. , \& Yamık, G. A. , (2016). The effect of field trips to informal learning environment on learning of "classification of living things": case of the natural history museum and botanical garden. Ege Journal of Education, 1 (17), 174-197.

16) Yıldırım, H.i. \& Şensoy, Ö. (2016). The effect of science festivals on 6th grade students' attitudes towards science course. International Journal of Turkish Education Sciences, 14 (1), 23-40. 